\title{
The Effect of Magnesium Oxide Supplementation to Aluminum Oxide Slip on the Jointing of Aluminum Oxide Bars
}

\author{
Tetsurou ODATSU ${ }^{1}$, Takashi SAWASE ${ }^{1}$, Kohji KAMADA ${ }^{1}$, Yohsuke TAIRA ${ }^{1}$, Takanobu SHIRAISHI ${ }^{2}$ and \\ Mitsuru ATSUTA ${ }^{1}$ \\ ${ }^{1}$ Department of Applied Prosthodontics, Graduate School of Biomedical Sciences, Nagasaki University, 1-7-1 Sakamoto, \\ Nagasaki 852-8588, Japan \\ ${ }^{2}$ Department of Dental and Biomedical Materials Science, Graduate School of Biomedical Sciences, Nagasaki University, \\ 1-7-1 Sakamoto, Nagasaki 852-8588, Japan \\ Corresponding author, Takashi SAWASE; E-mail: sawase@net.nagasaki-u.ac.jp
}

Received July 27, 2007/Accepted October 22, 2007

The purpose of this study was to investigate the effect of modifying aluminum oxide slips with magnesium oxide (MgO) to create a jointing material for In-Ceram ${ }^{\circledR}$ Alumina. Jointed In-Ceram ${ }^{\circledR}$ Alumina bars with In-Ceram ${ }^{\circledR}$ Alumina slips containing 0-1.0 mass\% $\mathrm{MgO}$ were examined by a three-point bending test. Joint-free bars were also tested as controls. Fracture surfaces were evaluated by scanning electron microscopy. In addition, linear shrinkage and fracture toughness were assessed.

The 0.3 mass\% $\mathrm{MgO}$ group showed the highest flexural strength among the jointed groups, and there were no statistical differences between the joint-free control groups. The fracture surface of 0.3 mass\% MgO group showed increased sintering densification with reduced micropore size. No linear shrinkage was observed with the addition of $\mathrm{MgO}$ to the alumina slip. Added $\mathrm{MgO}$ was also effective in boosting fracture toughness. The present findings indicate that the $\mathrm{MgO}$ supplemented binding material is useful for clinical applications.

Keywords: Aluminum oxide, Magnesium oxide, Jointing

\section{INTRODUCTION}

The mechanical properties of ceramic core materi$a^{1,2)}$ have improved considerably. As a result, allceramic restorations have allowed the construction of natural-looking and promising structures characterized by high color stability ${ }^{3)}$, low thermal conductivity, and high wear resistance. Although some zirconia-based ceramics have been used in esthetic dental restorations ${ }^{2,4)}$, zirconia usually renders the restoration opaque at the "esthetic zone" of the anterior maxillary jaw ${ }^{5,6)}$. In contrast, In-Ceram ${ }^{\circledR}$ Alumina (Vita Zahnfabrik, D-79704 Bad Säckingen, Germany) shows moderate translucency ${ }^{5,6)}$ and allows the adjustment of color by means of glass infiltration ${ }^{7,8)}$.

Clinically, core materials can be prepared by the slip-cast technique ${ }^{7}$, by milling using the CAD/CAM technique $^{9)}$, or by the electroforming technique ${ }^{10}$. Although excellent clinical outcomes for single crown restorations can be obtained with every preparation technique ${ }^{11,12)}$, ceramic copings fabricated by the $\mathrm{CAD} / \mathrm{CAM}$ technique are stronger than those fabricated by other techniques. Commercially available $\mathrm{CAD} / \mathrm{CAM}$ blocks have a minimal number of flaws and cracks, and they have a smaller range of fracture strength variation ${ }^{13,14)}$.

However, the maximum length of In-Ceram ${ }^{\circledR}$ Alumina blocks at $28 \mathrm{~mm}$ limits the fixed partial dentures to a three-unit design. There are also operative difficulties in applying this material to splinted crowns, which are often required in periodontal treatment and implant prostheses. The milling bar cannot reach a sharp embrasure without damaging the margin. Therefore, it is simply unfeasible to make multi-unit fixed partial dentures and/or splinted crowns using In-Ceram ${ }^{\circledR}$ Alumina Blanks.

The soldering technique is generally used for metal-based restorations. Clinically, it would be advantageous if sections of In-Ceram ${ }^{\circledR}$ coping could be jointed together. In-Ceram ${ }^{\circledR}$ Alumina Blanks with several connecting designs have been jointed with In-Ceram ${ }^{\circledR}$ Alumina slips. However, the fracture strength of jointed In-Ceram ${ }^{\circledR}$ Alumina bars was significantly lower than that of joint-free In-Ceram ${ }^{\circledR}$ Alumina bars ${ }^{14,15)}$.

To compensate for the low mechanical strength, Harmer and Brook $^{16)}$ have demonstrated that adding $\mathrm{MgO}$ to alumina accelerated densification and reduced pore size. The aim of the present study, therefore, was to investigate the effect of $\mathrm{MgO}$ supplementation to In-Ceram ${ }^{\circledR}$ Alumina on flexural strength, fracture toughness, and linear shrinkage.

\section{MATERIALS AND METHODS}

\section{Specimen preparation}

Table 1 lists the materials used in this study. A total of 128 test bars $(1.2 \times 4 \times 10 \mathrm{~mm})$ were machined from In-Ceram ${ }^{\circledR}$ Alumina Blanks (Vita, Batch No. 0602131; Table 1) using a low-speed cutting saw (Isomet, Buehler Corp., Lake Bluff, IL, USA), followed by abrasive paper grinding with a grain size of $\# 600$. 
Table 1 Experimental materials used in this study

\begin{tabular}{|c|c|c|c|c|}
\hline \multicolumn{2}{|r|}{ Material } & Chemical composition (mass\%) & \multicolumn{2}{|r|}{ Manufacturer } \\
\hline \multicolumn{2}{|c|}{ In-Ceram ${ }^{\circledR}$ Alumina Blank } & $\mathrm{Al}_{2} \mathrm{O}_{3}: 100$ & $\begin{array}{r}0602131 \\
7928\end{array}$ & $\begin{array}{l}\text { Vita Zahnfabrik, D-79704 Bad } \\
\text { Säckingen, Germany }\end{array}$ \\
\hline \multicolumn{2}{|c|}{ In-Ceram ${ }^{\circledR}$ Alumina Slip } & $\mathrm{Al}_{2} \mathrm{O}_{3}: 100$ & 26270 & $\begin{array}{l}\text { Vita Zahnfabrik, D-79704 Bad } \\
\text { Säckingen, Germany }\end{array}$ \\
\hline \multicolumn{2}{|c|}{ In-Ceram ${ }^{\circledR}$ Alumina Glass Power } & $\begin{array}{l}\mathrm{Al}_{2} \mathrm{O}_{3}: 14-17, \mathrm{SiO}_{2}: 14-17 \\
\mathrm{~B}_{2} \mathrm{O}_{3}: 12-15, \mathrm{TiO}_{2}: 3-5 \\
\mathrm{La}_{2} \mathrm{O}_{3}: 39-48, \mathrm{CeO}_{2}: 2-5 \\
\mathrm{CaO}: 2-4\end{array}$ & 7917 & $\begin{array}{l}\text { Vita Zahnfabrik, D-79704 Bad } \\
\text { Säckingen, Germany }\end{array}$ \\
\hline \multicolumn{2}{|l|}{$\mathrm{MgO}$} & $\mathrm{MgO}: 99.9$ & KLH1020 & $\begin{array}{l}\text { Wako Pure Chemical Industries, } \\
\text { Ltd., Osaka, Japan }\end{array}$ \\
\hline \multicolumn{5}{|c|}{ Table 2 Experimental and control groups in this study } \\
\hline \multicolumn{2}{|r|}{ Testing group } & \multicolumn{2}{|c|}{ Jointing material } & \\
\hline & CS & \multicolumn{2}{|c|}{-(Joint-free slip cast bar) } & \\
\hline & $\mathrm{CB}$ & \multicolumn{3}{|c|}{-(Joint-free In-Ceram Alumina Blanks) } \\
\hline & CJ & \multicolumn{3}{|c|}{ In-Ceram Alumina slip without $\mathrm{MgO}$} \\
\hline & J0.05 & \multicolumn{3}{|c|}{ In-Ceram Alumina slip with containig 0.05 mass $\% \mathrm{MgO}$} \\
\hline & J0.1 & \multicolumn{3}{|c|}{ In-Ceram Alumina slip with containig 0.1 mass $\% \mathrm{MgO}$} \\
\hline & J0.2 & \multicolumn{3}{|c|}{ In-Ceram Alumina slip with containig 0.2 mass $\% \mathrm{MgO}$} \\
\hline & J0.3 & \multicolumn{3}{|c|}{ In-Ceram Alumina slip with containig 0.3 mass $\% \mathrm{MgO}$} \\
\hline & J0.4 & \multicolumn{3}{|c|}{ In-Ceram Alumina slip with containig 0.4 mass $\% \mathrm{MgO}$} \\
\hline & J0.5 & \multicolumn{3}{|c|}{ In-Ceram Alumina slip with containig 0.5 mass $\% \mathrm{MgO}$} \\
\hline & J1.0 & \multicolumn{3}{|c|}{ In-Ceram Alumina slip with containig 1.0 mass $\% \mathrm{MgO}$} \\
\hline
\end{tabular}
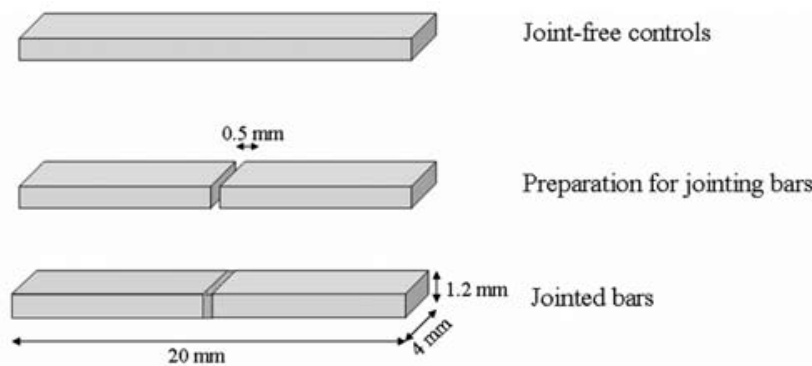

Fig. 1 Joint-free control bar and butt joint shape of jointed bars with a gap distance of $0.5 \mathrm{~mm}$.

To make the binding material, $0.05,0.1-0.5$, or 1.0 mass\% MgO (Wako Pure Chemical Industries Ltd., Osaka, Japan, Table 1) was mixed with In-Ceram ${ }^{\circledR}$ Alumina slip (Vita, Batch No. 26270; Table 1) for the experimental groups designated J0.05, J0.1-J0.5, and J1.0 respectively (Table 2). In-Ceram ${ }^{\circledR}$ Alumina slip without $\mathrm{MgO}$ was also prepared as a control (CJ).

The bar specimens were adjusted into a butt joint shape with two congruent opposing end surfaces forming a $90^{\circ}$ angle to the longitudinal axis of the bars. They were fixed on a custom-made gage with a distance of $0.5 \mathrm{~mm}$ between the connecting surfaces (Fig. 1). Distilled water was applied to moisten the surface, and then the jointing material (In-Ceram ${ }^{\circledR}$ Alumina slip with/without $\mathrm{MgO}$ ) was inserted into the gap using a brush. After drying, the jointed bend test bars were sintered in a porcelain furnace (Commodore 75 VPF, Jelenko, New York, USA) at $1120^{\circ} \mathrm{C}$ in accordance with the manufacturer's sintering schedule for the slip-cast technique (Table 3).

Joint-free bar specimens $(1.2 \times 4 \times 20 \mathrm{~mm})$, either machined from In-Ceram ${ }^{\circledR}$ Alumina Blanks (CB, Vita, Batch No. 7928; Table 1) or entirely fabricated from In-Ceram ${ }^{\circledR}$ Alumina slip (CS), were also prepared as controls. Eight bars $(n=8)$ were prepared for each group listed in Table 2.

After sintering, a mixture of In-Ceram ${ }^{\circledR}$ Alumina Glass Powder (Vita, Batch No. 7917; Table 1) and distilled water was applied to the bars. The bars were placed on a platinum metal foil (Ishifuku Metal Industry Co. Ltd., Tokyo, Japan) and glass infiltration firing was carried out as given in Table 3. Excess glass was removed by means of a carborun- 
Table 3 Schedules for sintering, glass infiltration, and glass control firing

\begin{tabular}{lccccc}
\hline \multicolumn{1}{c}{ Firing } & Preheating Temp. & Holding Time 1 & Heating Rate & Firing Temp. & Holding Time 2 \\
\hline Sintering & $100^{\circ} \mathrm{C}$ & $3 \mathrm{~min}$ & $20^{\circ} \mathrm{C} / \mathrm{min}$ & $1120^{\circ} \mathrm{C}$ & $120 \mathrm{~min}$ \\
Glass infiltration firing & $600^{\circ} \mathrm{C}$ & $2 \mathrm{~min}$ & $51^{\circ} \mathrm{C} / \mathrm{min}$ & $1110^{\circ} \mathrm{C}$ & $190 \mathrm{~min}$ \\
Glass control firing & $600^{\circ} \mathrm{C}$ & $0.1 \mathrm{~min}$ & $80^{\circ} \mathrm{C} / \mathrm{min}$ & $960^{\circ} \mathrm{C}$ & $10 \mathrm{~min}$ \\
\hline
\end{tabular}

dum point almost down on the surface and by sandblasting with $50-\mu \mathrm{m}$ aluminum oxide. Occasionally, repeated glass control firing and sandblasting were necessary until no more excess glass was visible.

According to the product information of InCeram $^{\circledR}$ Alumina from the manufacturer, both InCeram $^{\circledR}$ Alumina Blanks and Slip consist of $100 \%$ $\mathrm{Al}_{2} \mathrm{O}_{3}$. In other words, $\mathrm{MgO}$ was not contained in In-Ceram $^{\circledR}$ Alumina Blanks, Slip, or Glass Powder (Table 1).

\section{Three-point bending test}

A three-point bending test was carried out using a universal testing machine (Autograph AGS-10kNG, Shimadzu Corp., Kyoto, Japan) at a crosshead speed of $0.5 \mathrm{~mm} / \mathrm{min}$. Distance between two steel bearers supporting the bars was $15 \mathrm{~mm}$. The bars were positioned in the testing machine in such a way that the jointing interface was centered between the two steel bearers supporting the bars ${ }^{17)}$. Failure load was recorded in Newtons (N), and flexural strength (MPa) was calculated as follows ${ }^{17)}$ :

$\mathrm{M}=3 W l / 2 b d^{2}$

where $W$ is the failure load $(\mathrm{N}), l$ is the test span $(\mathrm{mm}), b$ is the width of specimen $(\mathrm{mm})$, and $d$ is the thickness of specimen ( $\mathrm{mm})$.

Following the three-point bending test of bar specimens, the next focus was on the jointing material itself. Three jointing materials of CJ, J0.3, and J1.0 were selected and investigated as follows. In order to clarify the effect of $\mathrm{MgO}$ supplementation, the fracture surfaces of the three representative jointing materials were observed using a scanning electron microscope (SEM; S-3500N, Hitachi HighTechnologies Corp., Tokyo, Japan). Further, linear shrinkage and fracture toughness were also assessed to determine their clinical applicability.

\section{SEM observation}

Additional specimens $(1.2 \times 4 \times 20 \quad \mathrm{~mm}) \quad$ were prepared, each consisting entirely of one of the representative jointing materials. After sintering (Table 3), all specimens were broken and the fracture surfaces of the specimens examined by SEM.

\section{Linear shrinkage}

Linear shrinkage on firing was investigated microscopically. Each jointing material was prepared and fired according to the same firing schedule as given in Table 3. During fabrication, two pieces of thin platinum foils (50 $\mu \mathrm{m}$ in thickness) were embedded at an interval of approximately $5 \mathrm{~mm}$ apart. Using a digital microscope (VHX-200/100F, Keyence Corp., Osaka, Japan), the distance between the platinum foils was measured in micrometers before and after firing. Five bars were prepared for each group, and the mean linear shrinkage ratio was calculated.

\section{Fracture toughness}

To determine fracture toughness, the indentation fracture method was used ${ }^{18,19)}$. Three rectangular bar specimens $(1.5 \times 4 \times 36 \mathrm{~mm})$ were prepared and fired according to the same firing schedule (Table 3) for each jointing material. Elastic modulus was measured using a universal testing machine (Type 5566S, Instron Co., MA, USA) at a crosshead speed of $0.1 \mathrm{~mm} / \mathrm{min}$. Distance between the two steel bearers supporting the specimen was $30 \mathrm{~mm}$.

The specimens were polished with \#1500 abrasive paper and diamond paste (Dia Glace, YETI Dentalprodukte GmbH., Engen, Germany) with a felt wheel. A load of $9.8 \mathrm{~N}$ was applied to the specimen surface for 15 seconds using a micro Vickers hardness tester (MVK-HI, Akashi Co., Kanagawa, Japan). Each specimen was indented 10 times. Length of the impression diagonal and that of the crack from the rectangular corner of the impression were measured using the digital microscope.

Vickers hardness number $(\mathrm{H})$ and fracture toughness $(\mathrm{Kc})$ were calculated as follows ${ }^{18)}$ :

$$
\begin{aligned}
& \mathrm{H}=1.8544 P /(2 a)^{2} \\
& \mathrm{Kc}=0.018(E / \mathrm{H})^{1 / 2}\left(P / C^{3 / 2}\right)
\end{aligned}
$$

where $E$ is the elastic modulus $(\mathrm{Pa}), P$ is the indentation load $(\mathrm{N}), a$ is the half length of the impression diagonal (m), and $C$ is the half length of the crack from the rectangular corner of the impression (m).

\section{Statistical analysis}

After equality of variance was examined by Levene's test, the average value of each experimental group 
were compared by one-way ANOVA and Tukey's compromise test using a statistical software (SPSS for Windows 11.5.1J, SPSS Japan Inc., Tokyo, Japan). Statistical significance was set at $\mathrm{p}>0.05$.

\section{RESULTS}

According to Levene's test, equality of variance was confirmed.

\section{Three-point bending test}

Figure 2 shows the mean flexural strengths and statistical groupings obtained from Tukey's compromise test. There were no statistically significant differences between the joint-free control groups (CS, CB). CJ had the lowest flexural strength (309 MPa), which was about $60 \%$ of the strength of joint-free control groups (CS, CB). Jointed groups with $\mathrm{MgO}$ had significantly higher flexural strength than CJ. Flexural strength of the jointed groups with $\mathrm{MgO}$

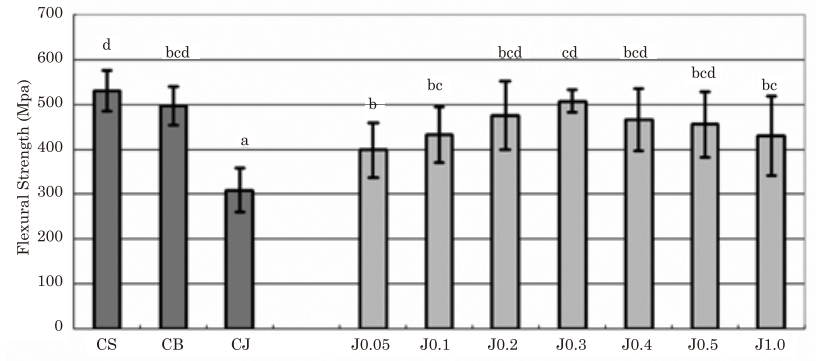

Fig. 2 Average flexural strengths with standard deviations (S.D.) and Tukey's compromise test groupings. Flexural strengths of sample groups with the same letters were not statistically different $(\mathrm{p}>0.05)$.

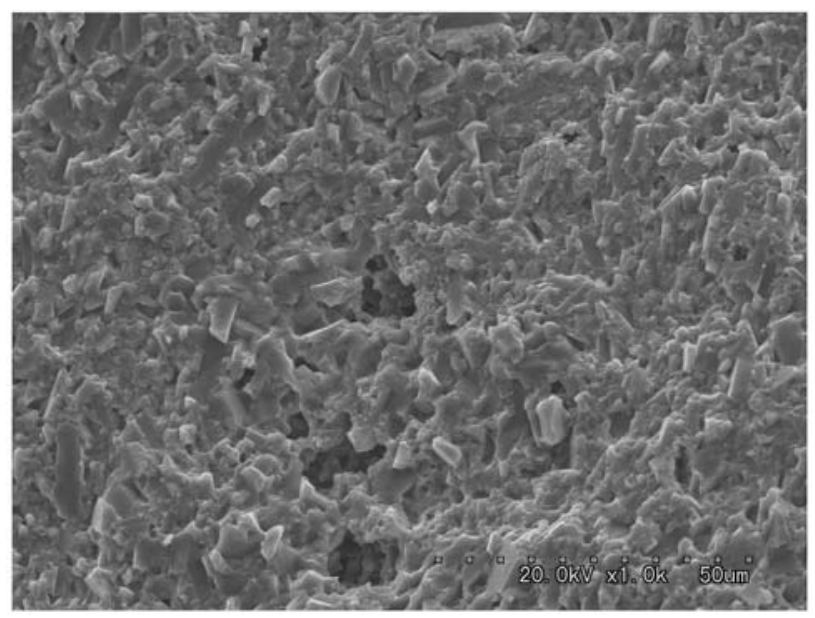

Fig. 3 SEM observation of the fracture surface of CJ. gradually increased from 0.05 mass $\%$ to 0.3 mass $\%$. However, concentrations higher than 0.3 mass\% had an adverse effect, leading to a gradual decrease in strength. No significant differences were detected among J0.2, J0.3, J0.4, J0.5, and the joint-free control groups (CS, CB).

\section{SEM observation}

All fracture surfaces showed a number of micropores (Figs. 3-5), and the pore size was obviously different in each sample. The jointing material of CJ showed pores of various sizes, from $1 \mu \mathrm{m}$ to $15 \mu \mathrm{m}$ (Fig. 3). The jointing material of J0.3, the group with the highest joint strength, contained relatively small pores ranging from $1 \mu \mathrm{m}$ to $3 \mu \mathrm{m}$ (Fig. 4). In the jointing material of J1.0, the pores were approximately $5 \mu \mathrm{m}$ in diameter (Fig. 5).

\section{Linear shrinkage}

The means and standard deviations in parentheses of

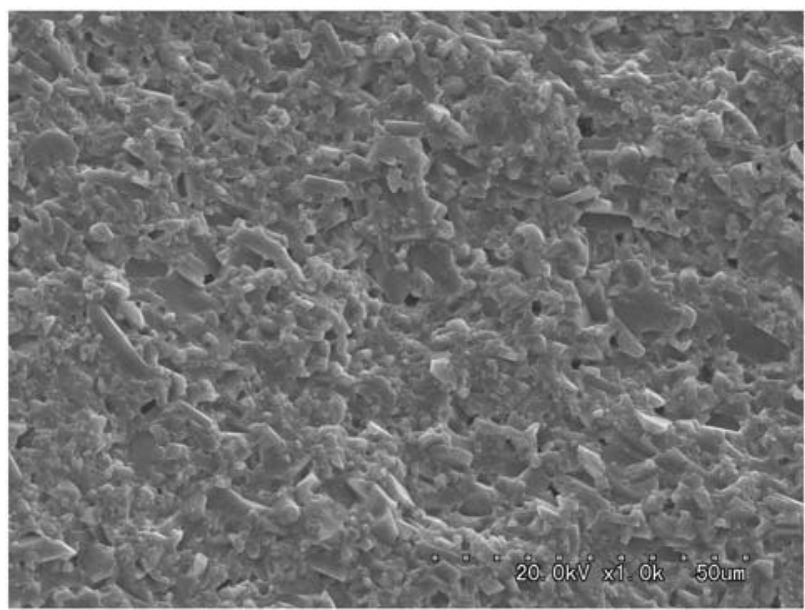

Fig. 4 SEM observation of the fracture surface of J0.3.

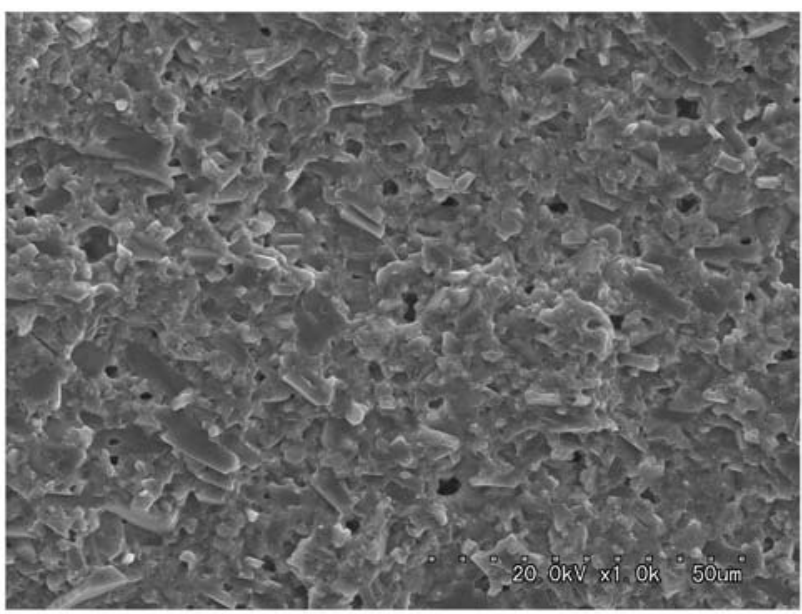

Fig. 5 SEM observation of the fracture surface of J1.0. 
Table 4 Mechanical properties of jointing materials. Sample groups with the same letters were not statistically different $(\mathrm{p}>0.05)$

\begin{tabular}{cccc}
\hline Testing group & Elastic modulus $(\mathrm{GPa})$ & Vickers hardness $(\mathrm{HV})$ & Fracture toughness $\left(\mathrm{MPa} \cdot \mathrm{m}^{1 / 2}\right)$ \\
\hline CJ & $309.2(42.8)^{\mathrm{a}}$ & $1169(56.4)^{\mathrm{a}}$ & $4.4(0.44)^{\mathrm{a}}$ \\
J0.3 & $278.1(11.5)^{\mathrm{a}}$ & $1173(50.6)^{\mathrm{a}}$ & $4.7(0.51)^{\mathrm{b}}$ \\
J1.0 & $254.6(11.4)^{\mathrm{a}}$ & $1101(40.6)^{\mathrm{b}}$ & $4.1(0.41)^{\mathrm{a}}$ \\
\hline
\end{tabular}

the linear shrinkage ratios calculated for the jointing materials CJ, J0.3, and J1.0 were $-0.25 \%$ (0.07), $-0.22 \%$ (0.04), and $-0.26 \%$ (0.03) respectively. Results showed that all specimens shrank slightly, regardless of the degree of $\mathrm{MgO}$ supplementation. No statistically significant differences were detected.

\section{Fracture toughness}

Table 4 shows the mean values of elastic modulus, Vickers hardness, and calculated fracture toughness of the jointing materials. J0.3 showed significantly higher fracture toughness than the others.

\section{DISCUSSION}

Jointing is discouraged for In-Ceram ${ }^{\circledR}$ Alumina frameworks, but there have been several trials to determine its utilization in conjunction with slip materials. Unfortunately, the technical difficulties related to slip technology have led to the appearance of voids and flaws at the interface ${ }^{15)}$ and microporosity in the jointing slip material ${ }^{14)}$, resulting in significantly lower flexural strength than joint-free controls $^{14,15)}$. In-Ceram ${ }^{\circledR}$ slip technology relies on the application of the slip material onto a special plaster surface, allowing moisture absorption into the plaster to promote particle agglomeration. However, when sections of In-Ceram ${ }^{\circledR}$ blocks are jointed together, the In-Ceram ${ }^{\circledR}$ blocks also tend to draw off water from the slip, making it difficult to place a new slip material in the connector area uniformly. In the current study, the blocks were transfused with distilled water prior to placing the slip material to prevent defect formation. This step thus allowed normal agglomeration of the slip material.

The In-Ceram ${ }^{\circledR}$ Alumina system consists of two three-dimensional interpenetrating phases: alumina and lanthanum glass. In this system, the alumina grains are partially sintered together to form necks between contiguous grains, resulting in an open-pore porous alumina network. Thereafter, lanthanum glass is infiltrated into this porous alumina structure to increase flexural strength. It is reported that the growth of interparticle contacts by surface diffusion can enhance flexural strength and fracture toughness of partially sintered porous alumina ${ }^{20}$. Therefore, control of the sintering mechanism and densification rate could play a key role in improving the strength of the porous alumina structure.

As for the role of $\mathrm{MgO}$, it is used as an additive to improve the strength and fracture toughness of partially sintered alumina and alumina glassinfiltrated ceramics. During alumina powder sintering, $\mathrm{MgO}$ greatly improves the homogeneity of the grain size, controls grain growth, and promotes the uniform wetting of alumina grains by liquid via an alteration in the interfacial energies, enabling the fabrication of ceramics with high densities ${ }^{16,21-25)}$.

In the current study, it was necessary to apply a load just on the jointing interface. On this ground, the three-point bending test was selected to determine the flexural strength. The MgO-supplemented groups had significantly higher flexural strength than CJ. Since the flexural strengths of the jointfree control groups were similar to those obtained in other studies ${ }^{14,26)}$, it was reasonable to assume that $\mathrm{MgO}$ supplementation indeed positively influenced the sintering mechanism of alumina. In addition, SEM observation of decrease in larger pores was not only consistent, but further endorsed the above flexural strength test results.

Theoretically, flexural strength should increase as $\mathrm{MgO}$ concentration becomes higher. However, in the present study, flexural strength decreased gradually at concentrations exceeding 0.3 mass\%. This was because agglomerated particles were formed and the alumina grains were not dispersed ${ }^{27,28)}$. As a result, inhomogeneous pores were formed in the alumina structure, changing the handling characteristic of the slip from that of a slurry to that of a downy paste. Indeed, SEM observation showed that J1.0 had larger pores, about $5 \mu \mathrm{m}$ in size, which were not seen in J0.3.

Sintering densification and reduced pore size also resulted in resistance against crack propagation in the fracture toughness test. In the current study, the indentation fracture method was used to determine fracture toughness. Maehara et al. ${ }^{19)}$ compared several formulas for calculating $\mathrm{K}_{\mathrm{IC}}$ values using the indentation fracture method to the single-edge precracked beam (SEPB) method. They concluded that the formula proposed in JIS R 1607 was substantially comparable to SEPB method and fully acceptable for 
$\mathrm{K}_{\mathrm{IC}}$ measurement of dental ceramics ${ }^{19)}$. According to the formula for fracture toughness calculation, crack length is one of the predominant factors affecting toughness.

With beneficial improvements in flexural strength and fracture toughness as mentioned above, the natural inclination was to suggest immediate clinical application. However, there remained a concern regarding shrinkage after sintering densification. It has been reported that the shrinkage ratio of In-Ceram ${ }^{\circledR}$ Alumina is $0.21 \%$, which is considered to be extremely low ${ }^{29)}$. Campbell et al. ${ }^{29)}$ reported that the mean grain size of In-Ceram ${ }^{\circledR}$ Alumina powder was $2.25 \mu \mathrm{m}$, with a wide size range from $0.1 \mu \mathrm{m}$ to $4 \mu \mathrm{m}$. Since $\mathrm{MgO}$-supplemented binding materials showed almost the same shrinkage ratio as In-Ceram ${ }^{\circledR}$ Alumina slip, it was apparent that $\mathrm{MgO}$ supplementation effected against the smaller particles to bind the network widely and tightly. The larger particles remained unchanged and maintained their distance during sintering.

Based on the results of this study, it could be said that In-Ceram ${ }^{\circledR}$ Alumina slip with an optimal supplementation of $\mathrm{MgO}$ was clinically useful - not only for jointing materials but also for marginal adaptation and additional configuration of the coping. The In-Ceram ${ }^{\circledR}$ system is equipped with an In-Ceram ${ }^{\circledR}$ Optimizer, which is a mixture of alumina powder and wax. It is used to fill small defects and adjust marginal discrepancies. Clearly, the strength of In-Ceram ${ }^{\circledR}$ Optimizer is lower due to the mixed wax. To circumvent this drawback, MgOsupplemented In-Ceram ${ }^{\circledR}$ Alumina slip can be used for marginal adaptation instead.

Recently, machined In-Ceram ${ }^{\circledR}$ copings have become popular with the advancement of CAD/CAM technology. However, the $\mathrm{CAD} / \mathrm{CAM}$ system renders an even thickness to the copings. This even thickness of the copings then renders the veneering porcelain too thick, resulting in a high probability of porcelain fracture ${ }^{30)}$. Copings with an anatomical form are one of the ways to prevent this kind of fracture. Using the current $\mathrm{MgO}$-supplemented In-Ceram ${ }^{\circledR}$ Alumina slip, we could then modify the configuration of the coping without diminishing its mechanical properties.

\section{CONCLUSION}

In-Ceram $^{\circledR}$ Alumina can be jointed using MgO-supplemented In-Ceram ${ }^{\circledR}$ Alumina slip. The 0.3 mass\% $\mathrm{MgO}$ supplemented In-Ceram ${ }^{\circledR}$ Alumina slip showed the highest flexural strength as well as high fracture toughness with negligible shrinkage. This new slip material seemed well poised to expand the clinical indications of In-Ceram ${ }^{\circledR}$ Alumina ceramic restorations.

\section{REFERENCES}

1) Guazzato M, Albakry M, Ringer SP, Swain MV. Strength, fracture toughness and microstructure of a selection of all-ceramic materials. Part I. Pressable and alumina glass-infiltrated ceramics. Dent Mater 2004; 20: 441-448.

2) Tinschert J, Natt G, Mautsch W, Augthun M, Spiekermann H. Fracture resistance of lithium disilicate-, alumina-, and zirconia-based three-unit fixed partial dentures: A laboratory study. Int $\mathrm{J}$ Prosthodont 2001; 14: 231-238.

3) Heydecke G, Zhang F, Razzoog ME. In vitro color stability of double-layer veneers after accelerated aging. J Prosthet Dent 2001; 85: 551-557.

4) Tinschert J, Zwez D, Marx R, Anusavice KJ. Structural reliability of alumina-, feldspar-, leucite-, mica- and zirconia-based ceramics. J Dent 2000; 28: 529-535.

5) Heffernan MJ, Aquilino SA, Diaz-Arnold AM, Haselton DR, Stanford CM, Vargas MA. Relative translucency of six all-ceramic systems. Part I: core materials. J Prosthet Dent 2002; 88: 4-9.

6) Heffernan MJ, Aquilino SA, Diaz-Arnold AM, Haselton DR, Stanford CM, Vargas MA. Relative translucency of six all-ceramic systems. Part II: core and veneer materials. J Prosthet Dent 2002; 88: 1015.

7) Pröbster L, Diehl J. Slip-casting alumina ceramics for crown and bridge restorations. Quintessence Int 1992; 23: 25-31.

8) Magne P, Belser U. Esthetic improvements and in vitro testing of In-Ceram Alumina and Spinell ceramic. Int J Prosthodont 1997; 10: 459-466.

9) Rinke S, Hüls A. Copy-milled aluminous core ceramic crowns: a clinical report. J Prosthet Dent 1996; 76: 343-346.

10) DiTolla M. A material improvement: Wol-Ceram. Dental Economics 2004; 94: 98-100.

11) Scotti R, Catapano S, D’Elia A. A clinical evaluation of In-Ceram crowns. Int J Prosthodont 1995; 8: 320323.

12) Bindl A, Mörmann WH. An up to 5-year clinical evaluation of posterior In-Ceram CAD/CAM core crowns. Int J Prosthodont 2002; 15: 451-456.

13) Hornberger H, Marquis PM, Christiansen S, Strunk HP. Microstructure of a high strength alumina glass composite. J Mater Res 1996; 11: 855-858.

14) Apholt W, Bindl A, Lüthy H, Mörmann WH. Flexural strength of Cerec 2 machined and jointed InCeram-Alumina and InCeram-Zirconia bars. Dent Mater 2001; 17: 260-267.

15) Sorensen JA, Knode H. Flexural strength of InCeram bars joined together by various methods. Quintessence Dent Technol 1996; 19: 123-125.

16) Harmer MP, Brook RJ. The effect of $\mathrm{MgO}$ additions on the kinetics of hot pressing in $\mathrm{Al}_{2} \mathrm{O}_{3}$. J Mater Sci 1980; 15: 3017-3024.

17) International Organization for Standardization. ISO 6872: 1995(E), Dental ceramics, 2nd ed., 1995, Geneva, Switzerland.

18) Japanese Standard Association. Japanese Indus- 
trial Standard JIS R 1607: 1995, Testing methods for fracture toughness of fine ceramics, 1995, Tokyo, Japan.

19) Maehara S, Fujishima A, Hotta $Y$, Miyazaki $T$. Fracture toughness measurement of dental ceramics using the indentation fracture method with different formulas. Dent Mater J 2005; 24: 328-334.

20) Nanjangud SC, Brezny R, Green DJ. Strength and Young's modulus behavior of a partially sintered porous alumina. J Am Ceram Soc 1995; 78: 266268.

21) Coble RL. Sintering crystalline solids. II. Experimental test of diffusion models in powder compacts. J Appl Phys 1961; 32: 793-799.

22) Bateman CA, Bennison SJ, Harmer MP. Mechanism for the role of magnesia in the sintering of alumina containing small amounts of a liquid phase. J Am Ceram Soc 1989; 72: 1241-1244.

23) Bennison SJ, Harmer MP. Effect of MgO solute on the kinetics of grain growth in $\mathrm{Al}_{2} \mathrm{O}_{3}$. J Am Ceram Soc 1983; 66: C90-C92.

24) Bennison SJ, Harmer MP. Grain-growth kinetics for alumina in the absence of a liquid phase. J Am
Ceram Soc 1985; 68: C22-C24.

25) Xiao-ping L, Jie-mo T, Yun-long Z, Ling W. Strength and fracture toughness of $\mathrm{MgO}$-modified glass infiltrated alumina for CAD/CAM. Dent Mater 2002; 18: 216-220.

26) Seghi RR, Sorensen JA. Relative flexural strength of six new ceramic materials. Int $J$ Prosthodont 1995; 8: 239-246.

27) Tari G, Ferreira JMF, Lyckfeldt O. Influence of magnesia on colloidal processing of alumina. J Eur Ceram Soc 1997; 17: 1341-1350.

28) Tsetsekou A, Agrafiotis C, Milias A. Optimization of the rheological properties of alumina slurries for ceramic processing applications. Part I: Slip-casting. J Eur Ceram Soc 2001; 21: 363-373.

29) Campbell SD, Pelletier LB, Pober RL, Giordano RA. Dimensional and formation analysis of a restorative ceramic and how it works. J Prosthet Dent 1995; 74: 332-340.

30) Sadan A, Blatz MB, Lang B. Clinical considerations for densely sintered alumina and zirconia restorations: Part 1 . Int $\mathrm{J}$ Periodontics Restorative Dent 2005; 25: 213-219 